This item was submitted to Loughborough's Research Repository by the author.

Items in Figshare are protected by copyright, with all rights reserved, unless otherwise indicated.

\title{
Studies on metal gluconic acid complexes
}

PLEASE CITE THE PUBLISHED VERSION

PUBLISHER

(C) Materials Resource Society

LICENCE

CC BY-NC-ND 4.0

REPOSITORY RECORD

Warwick, Peter, Nicholas D.M. Evans, and Sarah Vines. 2019. "Studies on Metal Gluconic Acid Complexes". figshare. https://hdl.handle.net/2134/3144. 
This item was submitted to Loughborough's Institutional Repository by the author and is made available under the following Creative Commons Licence conditions.

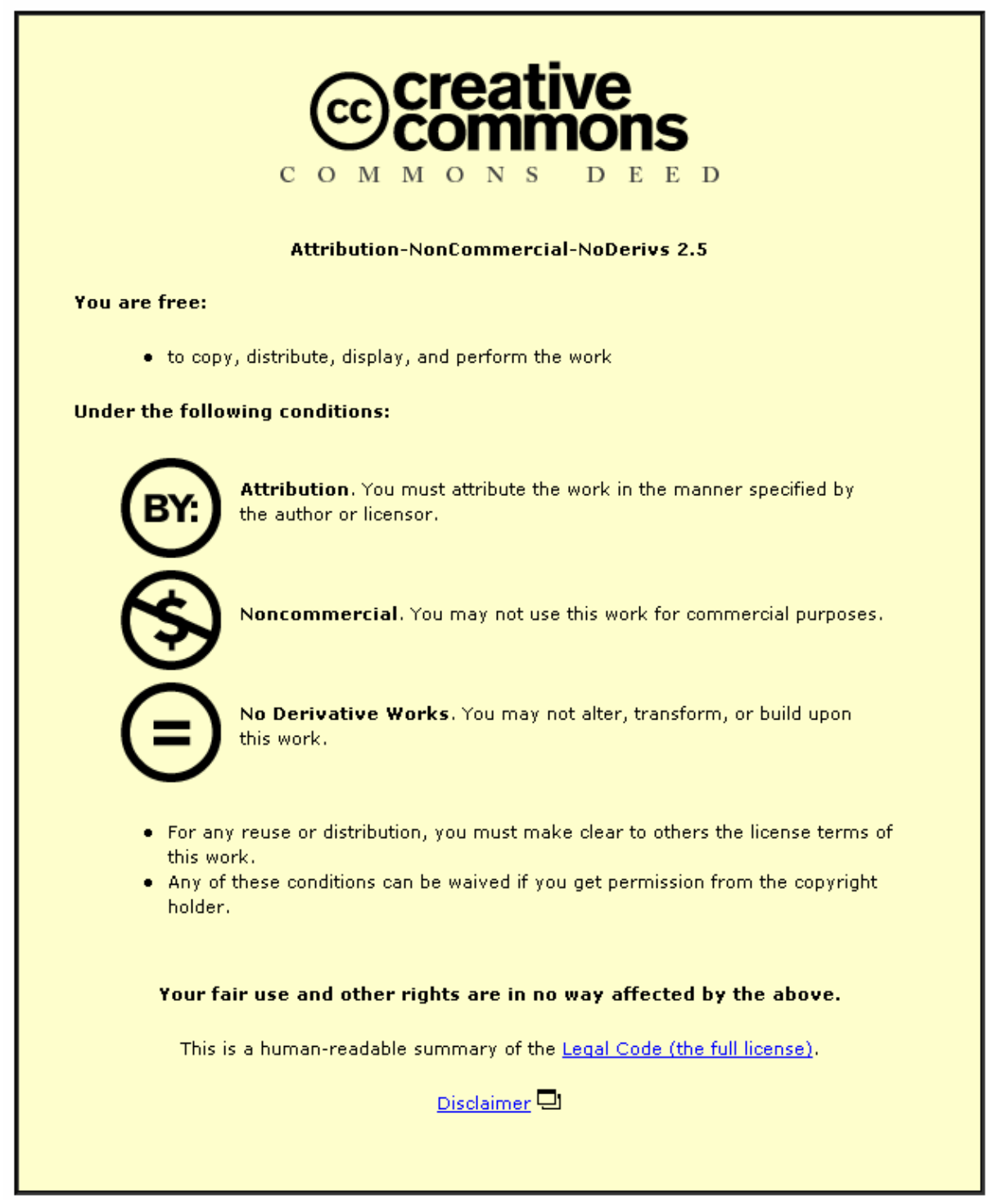

For the full text of this licence, please go to: http://creativecommons.org/licenses/by-nc-nd/2.5/ 


\title{
Studies on Metal Gluconic Acid Complexes
}

Peter Warwick, ${ }^{1}$ Nick Evans ${ }^{1}$ and Sarah Vines ${ }^{2}$

${ }^{1}$ Department of Chemistry, Loughborough University, Loughborough, Leics., LE11 3TU, UK

${ }^{2}$ United Kingdom Nirex Limited, Curie Avenue, Harwell, Didcot, Oxon. OX11 0RH, UK

\begin{abstract}
The presence of organic complexants, such as gluconic acid, in an intermediate-level radioactive-waste (ILW) repository may have a detrimental effect on the sorption of radionuclides, by forming organic complexes in solution. In order to assess this, stability constants are required for the complexes formed with radionuclides at high $\mathrm{pH}$. This study reports the stability constants for the reactions of metals with gluconic acid (Gl). The metals studied were $\mathrm{Cd}, \mathrm{Ce}, \mathrm{Co}, \mathrm{Eu}, \mathrm{Fe}(\mathrm{II}), \mathrm{Fe}(\mathrm{III})$, Ho and U(VI) at $\mathrm{pH} 13.3$; and $\mathrm{Ce}$, Co and U(VI) at $\mathrm{pH}$ 7. The constants were measured by the Schubert (ion-exchange) or solubility product methods. Stoichiometries of the complexes were also determined. At $\mathrm{pH} 7$ each complex was of the form $\mathrm{M}_{1} \mathrm{Gl}_{1}$, with $\log \beta$ values suggestive of salt formation. The $\mathrm{M}^{2+} \log \beta$ values were between 13 and 20. For $\mathrm{M}^{3+}$, there was less consistency. The $\mathrm{M}_{2} \mathrm{Gl}_{1}$ complexes (Ho \& Ce) had values of 49.8 and 43.9 , whereas the $\mathrm{M}_{1} \mathrm{Gl}_{1}$ type (Fe(III) \& Eu) range from 24 to 38 . The constants have enabled speciation calculations to be performed showing the effect of gluconic acid on the metal's solubility. Solubility is predicted to increase in the presence of gluconic acid from $\mathrm{pH} 9$ to 13.5, suggesting that gluconic acid may have an impact on radionuclide behaviour. The largest increases in solubility are for $\mathrm{Cd}, \mathrm{Co}, \mathrm{Eu}, \mathrm{Ho}$ and $\mathrm{Ni}$, the smallest is with U(VI).
\end{abstract}

\section{INTRODUCTION}

The Nirex Phased Geological Repository Concept involves the use of a cementitious backfill to provide a chemical barrier to radionuclide migration from the near field [1]. The backfill chemically conditions the porewater to provide a high $\mathrm{pH}$ under which the solubility of many radionuclides is low. The backfill also provides a large surface area for radionuclide sorption. The presence of organic complexants may increase the solubility and decrease the sorption of radionuclides by forming soluble organic complexes [2], thereby increasing their mobility in the near field and alkaline-disturbed zones. Gluconic acid, $\mathrm{CO}_{2} \mathrm{H}(\mathrm{CHOH})_{4} \mathrm{CH}_{2} \mathrm{OH}$, is a polyhydroxylated carboxylic acid with potentially labile hydroxyl protons that can be displaced during metal complexation at high $\mathrm{pH}$. Its possible presence in a cementitious ILW repository as a cement additive has been reported elsewhere [3]. Stability constants are required for the reactions of radionuclides with gluconic acid at high $\mathrm{pH}$, in order to calculate the effect on radionuclide migration. To date the NiGl [4] constant has been reported. The work reported here adds constants for $\mathrm{Cd}, \mathrm{Ce}, \mathrm{Co}, \mathrm{Eu}, \mathrm{Fe}(\mathrm{II}), \mathrm{Fe}(\mathrm{III}), \mathrm{Ho}, \mathrm{U}(\mathrm{IV})$ and $\mathrm{U}(\mathrm{VI})$ at $\mathrm{pH}$ 13.3; and $\mathrm{Ce}, \mathrm{Co}$ and $\mathrm{U}(\mathrm{VI})$ at $\mathrm{pH}$ 7. Some of these elements will have radionuclides that will be present in the repository, and some are useful analogue or "model" elements for important radionuclides. All constants except for U(VI) at high $\mathrm{pH}$ were measured by the Schubert method [4]. The solubility product method [2] was used for measuring the constant for U(VI) at $\mathrm{pH} 13.3$. The stoichiometries of the complexes, and the number of $\mathrm{OH}^{-}$ions involved in the reactions, were determined using Bjerrum plots, conductometric titrations and spectrophotometric methods [4].

The constants were derived using the Schubert expression (equation 1) [5]: 


$$
\log \left(\frac{D_{0}}{D}-1\right) A=\log \beta+z \log [G 1]
$$

$D$ describes the distribution of metal between resin $\left[\mathrm{M}_{\mathrm{res}}\right]$ and solution phase $\left[\mathrm{M}_{\mathrm{sol}}\right]$ in the presence of ligand, and $\mathrm{D}_{0}$ in the absence of ligand [4]. The side-reaction coefficient (A term) is defined as discussed by Maes et al. [5] for complexes containing one cation $(n=1)$. However, if $\mathrm{n}=2$ a different expression is obtained (equation 3 ) [4]:

$$
\beta=\frac{A^{2} D_{0}}{\left[M_{\text {sol }}\right][G l]^{z}[O H]^{y} D}\left(\frac{D_{0}}{D}-1\right)
$$

\section{EXPERIMENTAL}

Deionised water from a Barnstead NANOpure ultrapure system and AR reagents were used throughout. Radionuclides $\left({ }^{109} \mathrm{Cd},{ }^{141} \mathrm{Ce},{ }^{57} \mathrm{Co},{ }^{59} \mathrm{Fe},{ }^{152} \mathrm{Eu},{ }^{233} \mathrm{U}\right)$ were obtained from Amersham. BioRad 50W-X2 cation exchange resin was used in the measurements. $\mathrm{pH}$ was measured with an Orion 720A glass electrode. Spectrophotometric absorbances were measured using $1 \mathrm{~cm}$ silica cells in a Philips PU8730 UV/Vis spectrophotometer. A Jenway 4310 meter was used to measure conductivity. $\beta$-emitting isotopes were counted by liquid scintillation counting in Ecoscint using a Canberra Packard TRI-Carb 2750TR/LL. $\Gamma$-emitters were counted on a Packard Cobra II Auto-Gamma. Ho was measured by ICP-MS with PFA nebuliser on a VG PQ ExCell instrument.

Full details of all methods for the measurement of stoichiometry, except the precipitate absorption method, are given in Warwick et al. [4]. For the precipitate absorption method, solutions containing Co $\left(0.01 \mathrm{~mol} \mathrm{dm}^{-3}\right)$, excess $\mathrm{NaGl}\left(0.05 \mathrm{~mol} \mathrm{dm}^{-3}\right)$, and varying amounts of $\mathrm{NaOH}$ to give $\mathrm{OH}^{-}: \mathrm{Co}$ mole ratios up to $4: 1$ were adjusted with $0.1 \mathrm{~mol} \mathrm{dm}^{-3} \mathrm{KNO}_{3}$ to give constant ionic strength and equilibrated for 1 week under $\mathrm{N}_{2}$, to prevent auto-oxidation. Absorbances were measured at $281 \mathrm{~nm}$.

In the Schubert method, 5 measurements were made for each point at $25{ }^{\circ} \mathrm{C}$ in $20 \mathrm{~cm}^{3}$ polypropylene vials containing 1000 and $100 \mathrm{mg}$ resin for di- and trivalent cations respectively. $15 \mathrm{~cm}^{3}$ aliquots of $\mathrm{Na}$ gluconate solution, $\mathrm{pH}$ adjusted with $\mathrm{NaOH}$, were spiked with ${ }^{107} \mathrm{Cd}$,

${ }^{131} \mathrm{Ce},{ }^{57} \mathrm{Co},{ }^{152} \mathrm{Eu},{ }^{57} \mathrm{Fe}$ or ${ }^{233} \mathrm{U}$ giving a metal concentration between $10^{-8}$ and $10^{-9} \mathrm{~mol} \mathrm{dm}{ }^{-3}$, and equilibrated in a shaker bath for 72 hours. One set of vials was used to check for wall sorption. $1 \mathrm{~cm}^{3}$ of supernatant liquid was withdrawn, through a $0.45 \mu \mathrm{m}$ filter, and the activity measured. Full details of the solubility product approach are given in Warwick et al. [6].

\section{RESULTS}

\section{Bjerrum plots}

Full details are given for $\mathrm{Cd}$, and curves are shown for $\mathrm{Cd}$, Ce and Co (Fig. 1). Data for all metals were interpreted similarly. Cadmium gluconate (Cd-Gl) appeared to form 3 complexes. Below pH 7.9, a colourless soluble complex was formed. Above 7.9, a white precipitate occurred, which partially dissolved above $\mathrm{pH} 11$. There was no evidence for $\mathrm{OH}^{-}$participation in the formation of the soluble complex, but there was evidence for a $1: 2(\mathrm{Cd}: \mathrm{OH})$ ratio in the complex formed above $\mathrm{pH} 11$, as shown by the inflexion in the plot. 


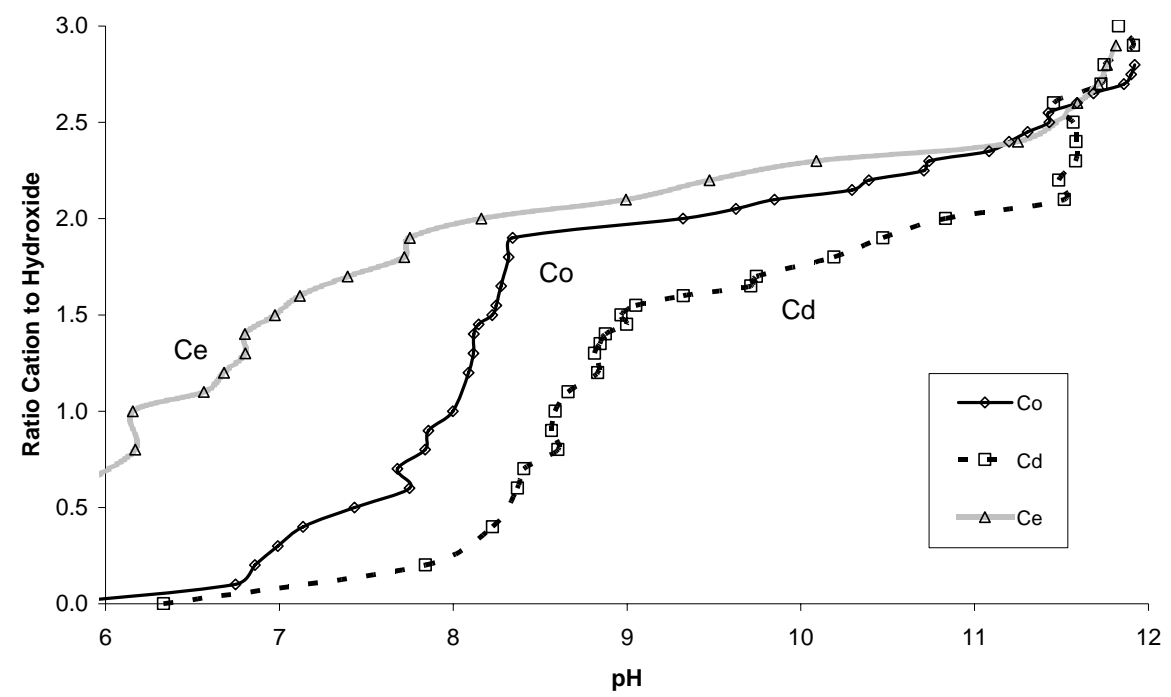

Figure 1. Bjerrum plots for $\mathrm{Cd}, \mathrm{Ce}$ and $\mathrm{Co}$.

\section{Conductometric titrations}

Plots for Co (Fig. 2) are described in detail. Plots for the other metals were similar. The conductance changes during the titration, as metal ions are added. A change in the gradient indicates the point at which the ions are in the same stoichiometric ratio to each other as in the complex. Metal ions added after this point are not complexed by gluconate. Each point is the mean of 3 measurements. Line $\mathrm{B}$ shows a $\mathrm{Co}: \mathrm{OH}^{-}$ratio of $1: 2$ in the complex (change in gradient at $10 \mathrm{~cm}^{3}$ ). Line $\mathrm{C}$ shows a Co:Gl ratio of $1: 1$ in the complex formed when there are $1.5 \mathrm{OH}^{-}$ions to every $\mathrm{Co}^{2+}$ present (significant gradient change from 1.40 to 1.57 at $10 \mathrm{~cm}^{3}$ with $\mathrm{R}^{2}>0.99$ ).

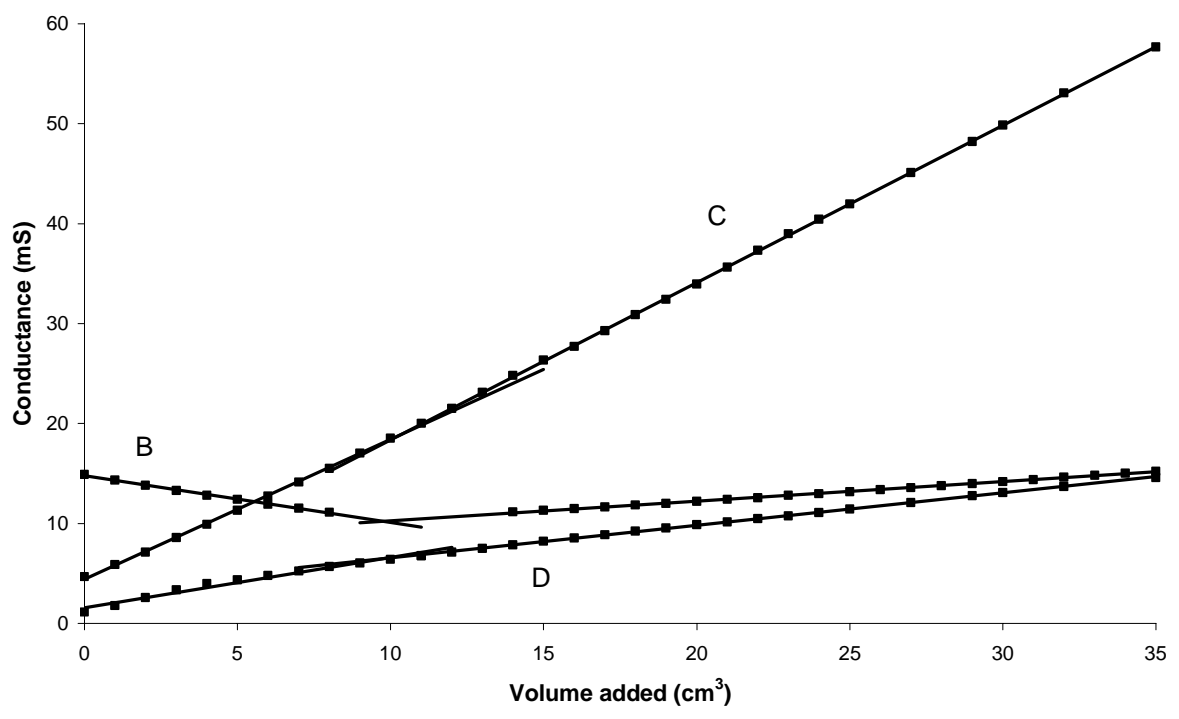

Figure 2. Conductometric titrations for cobalt gluconate. 
Line $\mathrm{D}$ shows the formation of a complex with a Co:Gl ratio of 1:1, when there are two $\mathrm{OH}^{-}$ ions to every $\mathrm{Co}^{2+}$ ion (significant gradient change from 0.503 to 0.325 at $10 \mathrm{~cm}^{3}$ with $\mathrm{R}^{2}>0.99$ ).

\section{$\underline{\text { Spectrophotometric studies }}$}

Only Co showed an absorbance peak for the complex, sufficiently separate from the metal and its hydrolysis products to use spectrophotometric methods for analysis.

\section{Precipitate absorbance method}

Absorbances were measured at high $\mathrm{pH}$. The minima showed the complex formed at high $\mathrm{pH}$ had a mole ratio of 1:2, and the one formed at intermediate $\mathrm{pH}$ a mole ratio of 2:3.

\section{Measurement of stability constants by the Schubert method}

\section{Cadmium}

The stability constants used to calculate the A term were $\log \beta\left(\mathrm{Cd}(\mathrm{OH})_{2}\right)=7.7, \mathrm{Cd}(\mathrm{OH})_{3}{ }^{-}=$ 10.3 and $\mathrm{Cd}(\mathrm{OH})_{4}{ }^{2-}=8.7$ [7]. At pH 13.3, the stoichiometry of the complex was found to be $\mathrm{CdGl}(\mathrm{OH})_{2}$. The derived value for the stability constant was $\log \beta=14.2 \pm 0.2$. In other studies, Blomqvist et al [8] suggested the formation of $\mathrm{Cd}_{2} \mathrm{Gl}_{2}{ }^{2-}$ and Melton [9] postulated the precipitate as being $\mathrm{Cd}_{3} \mathrm{Gl}_{2}(\mathrm{OH})_{4} \cdot 2 \mathrm{H}_{2} \mathrm{O}$. Pecsok [10] found $\mathrm{Cd}_{2} \mathrm{Gl}_{3}(\mathrm{OH})_{2}{ }^{4-}(\log \beta=10.2)$ and $\mathrm{Cd}_{2} \mathrm{Gl}(\mathrm{OH})_{4}{ }^{-}$ $(\log \beta=8.7)$ between $\mathrm{pH} 13$ and 14 . None of these high $\mathrm{pH}$ species was found in this study, but the diversity of results suggests that this is a complicated system which requires more study. A summary of the stoichiometries and measured stability constants are shown in tables I to III, arranged by $\mathrm{pH}$.

Table I. Summary of stoichiometric results from acidic and near-neutral $\mathrm{pH}$ range.

\begin{tabular}{|c|c|c|c|c|c|c|c|}
\hline Metal & Solution & $\mathbf{p H}$ & $\begin{array}{c}\text { Bjerrum } \\
\text { plot }\end{array}$ & $\begin{array}{c}\text { Conductometric } \\
\text { titrations } \\
\text { (M:Gl) }\end{array}$ & $\begin{array}{c}\text { Schubert } \\
\text { slope } \\
\text { (M:Gl) }\end{array}$ & $\begin{array}{c}\text { Species } \\
\text { formed }\end{array}$ & Log $\boldsymbol{\beta}$ \\
\hline $\mathrm{Cd}$ & Colourless & $<7.9$ & $\mathrm{No} \mathrm{OH}$ & $1: 1$ & $1: 1$ & $\mathrm{CdGl}$ & \\
\hline $\mathrm{Ce}$ & Colourless & $<7.6$ & $\mathrm{No} \mathrm{OH}$ & $1: 1$ & $1: 1$ & $\mathrm{CeGl}$ & $2.5 \pm 0.8$ \\
\hline $\mathrm{Co}$ & Pink/Purple & $<7.3$ & $\mathrm{No} \mathrm{OH}$ & & $1: 1$ & $\mathrm{CoGl}$ & $1.0 \pm 0.4$ \\
\hline $\mathrm{Eu}$ & Colourless & $<6.1$ & $\mathrm{No} \mathrm{OH}$ & $1: 1$ & $1: 1$ & $\mathrm{EuGl}$ & \\
\hline $\mathrm{Ho}$ & Pink & $<6.4$ & $\mathrm{No} \mathrm{OH}$ & $1: 1$ & & $\mathrm{HoGl}$ & \\
\hline $\mathrm{Fe}(\mathrm{II})$ & Yellow & $<6.7$ & $\mathrm{No} \mathrm{OH}$ & $1: 1$ & $1: 1$ & $\mathrm{FeGl}$ & \\
\hline $\mathrm{Fe}(\mathrm{III})$ & Green & $<3.2$ & $\mathrm{No} \mathrm{OH}$ & $1: 1$ & $1: 1$ & $\mathrm{FeGl}$ & \\
\hline $\mathrm{U}(\mathrm{VI})$ & Yellow & $6-13.5$ & $\mathrm{No} \mathrm{OH}$ & $1: 1$ & & $\mathrm{UO}_{2} \mathrm{Gl}$ & $6.3 \pm 0.4$ \\
\hline
\end{tabular}


Table II. Summary of stoichiometric results from high $\mathrm{pH}$ range.

\begin{tabular}{|c|c|c|c|c|c|c|c|c|}
\hline \multirow{2}{*}{$\begin{array}{l}\text { Metal } \\
\text { Ratio }\end{array}$} & \multirow[t]{2}{*}{ Solution } & \multirow[t]{2}{*}{ pH } & \multirow{2}{*}{$\begin{array}{c}\begin{array}{c}\text { Bjerrum } \\
\text { plot }\end{array} \\
\text { M:OH }\end{array}$} & \multicolumn{2}{|c|}{$\begin{array}{l}\text { Conductometric } \\
\text { titrations }\end{array}$} & \multirow{2}{*}{$\begin{array}{c}\begin{array}{c}\text { Schubert } \\
\text { slope }\end{array} \\
\text { M:Gl }\end{array}$} & \multirow[t]{2}{*}{$\begin{array}{l}\text { Species } \\
\text { formed }^{\mathrm{a}}\end{array}$} & \multirow[t]{2}{*}{$\log \beta$} \\
\hline & & & & M:OH & M:GI & & & \\
\hline $\mathrm{Cd}$ & White ppt & $>11$ & $1: 2$ & $1: 2$ & $1: 1$ & & $\mathrm{CdGl}(\mathrm{OH})_{2}$ & $14.2 \pm 0.2$ \\
\hline $\mathrm{Ce}$ & White ppt & $>7.6$ & $1: 2$ & $1: 2$ & $2: 1$ & & $\mathrm{Ce}_{2} \mathrm{Gl}(\mathrm{OH})_{4}$ & $43.9 \pm 0.6$ \\
\hline Co & Purple & $>11.8$ & $1: 2$ & $1: 2$ & $1: 1$ & & $\mathrm{CoGl}(\mathrm{OH})_{2}$ & $13.1 \pm 0.8$ \\
\hline $\mathrm{Eu}$ & Colourless & $>7.7$ & $1: 4$ & $1: 4$ & $1: 1$ & $1: 1$ & $\mathrm{EuGl}(\mathrm{OH})_{4}$ & $24.3 \pm 0.3$ \\
\hline Ho & Colourless & $>9$ & $1: 3$ & $1: 3$ & $2: 1$ & & $\mathrm{Ho}_{2} \mathrm{Gl}(\mathrm{OH})_{6}$ & $49.8 \pm 0.4$ \\
\hline $\mathrm{Fe}(\mathrm{II})$ & Green & $>7.4$ & $1: 4$ & $1: 4$ & $1: 1$ & & $\mathrm{FeGl}(\mathrm{OH})_{4}$ & $17.8 \pm 0.9$ \\
\hline $\mathrm{Fe}(\mathrm{III})$ & Green & $>3.9$ & $1: 3$ & $1: 3$ & $1: 1$ & $1: 1$ & $\mathrm{FeGl}(\mathrm{OH})_{3}$ & $37.9 \pm 1.2$ \\
\hline $\mathrm{U}(\mathrm{VI})$ & Yellow & $6-13.5$ & No OH & & $1: 1$ & & $\mathrm{UO}_{2} \mathrm{Gl}$ & $19.9 \pm 2$ \\
\hline
\end{tabular}

Table III. Summary of stoichiometric results from intermediate $\mathrm{pH}$ range.

\begin{tabular}{|c|c|c|c|c|c|c|c|c|}
\hline Metal & Description & $\mathbf{p H}$ & $\begin{array}{c}\text { Precipitate } \\
\text { absorbance } \\
\text { method }\end{array}$ & $\begin{array}{c}\text { Bjerrum } \\
\text { plot }\end{array}$ & \multicolumn{2}{c|}{$\begin{array}{c}\text { Conductometric } \\
\text { titrations }\end{array}$} & $\begin{array}{c}\text { Schubert } \\
\text { slope }\end{array}$ & $\begin{array}{c}\text { Species } \\
\text { formed }\end{array}$ \\
\hline Ratio & & & M:OH & M:OH & M:Gl & M:OH & M:Gl & \\
\hline $\mathrm{Cd}$ & White ppt & $7.9-11$ & & $1: 2$ & $1: 1$ & $1: 2$ & & $\mathrm{CdGl}_{(\mathrm{OH})_{2}}$ \\
\hline $\mathrm{Co}$ & Pink ppt & $7.3-11.8$ & $2: 3$ & & $1: 1$ & & & $\mathrm{Co}_{2} \mathrm{Gl}_{2}(\mathrm{OH})$ \\
\hline $\mathrm{Eu}$ & White ppt & $6.1-7.7$ & & $\mathrm{No} \mathrm{OH}$ & & & & \\
\hline $\mathrm{Ho}$ & White ppt & $6.4-9$ & & $1: 2$ & $2: 1$ & & & \\
\hline $\mathrm{Fe}^{2+}$ & Green ppt & $6.7-7.4$ & & $\mathrm{No} \mathrm{OH}$ & & & & \\
\hline $\mathrm{Fe}^{3+}$ & $\begin{array}{c}\text { Green- } \\
\text { Brown ppt }\end{array}$ & $3.2-3.9$ & & $1: 1$ & $1: 1$ & & $1: 1$ & \\
\hline
\end{tabular}

\section{Cerium}

At $\mathrm{pH} 7$, the complex was determined to be 1:1, i.e. CeGl. The derived value for the stability constant was $\log \beta=2.5 \pm 0.8$. It was assumed that the significant species were $\mathrm{Ce}^{3+}$ and $\mathrm{CeOH}^{2+}$, for which $\log \beta=4.9$ [7]. The Schubert plot for this complex also indicated a 1:1 Ce:Gl ratio. $\log \beta=2.36$ was obtained for CeGl by Marcu et al. [11]. At pH 13.3, the complex was determined to be $\mathrm{Ce}_{2} \mathrm{Gl}(\mathrm{OH})_{4}$, which gave a value of $\log \beta=43.9 \pm 0.6$. Calculation of the A term assumed that the significant species were $\mathrm{Ce}^{3+}$ and $\mathrm{Ce}(\mathrm{OH})^{4-}(\log \beta=16.4$ [12]). 


\section{Cobalt}

At $\mathrm{pH} 7$, the stoichiometry of the complex was determined to be 1:1, i.e. CoGl, with a stability constant of $\log \beta=1.0 \pm 0.4$. The A term was calculated on the assumption that the only significant species present was $\mathrm{Co}^{2+}$. The Schubert plot also indicated that the M:L ratio was 1:1. At $\mathrm{pH} 13.3$, the complex was found to be $\mathrm{CoGl}(\mathrm{OH})_{2}$. The derived value was $\log \beta=$ $13.1 \pm 0.8$. It was assumed that the significant species present was $\mathrm{HCoO}_{2}^{-}$. The constant used was $(\log \beta=9.20[12])$. Pickering et al. have shown the presence of an anionic complex at high $\mathrm{pH}$ [13] with between 1.5 and $2 \mathrm{OH}^{-}$ions per Co involved in the complex. Various authors [14] [15] [16] also found a 1:1 Co:Gl stoichiometry. Ashton et al. postulated that the insoluble species formed at $\mathrm{pH} 7.5$ were $\mathrm{Co}_{2} \mathrm{Gl}(\mathrm{OH})_{3} \cdot \mathrm{xH}_{2} \mathrm{O}$ and $\mathrm{Co}_{3} \mathrm{Gl}_{2}(\mathrm{OH})_{2} \cdot 2 \mathrm{H}_{2} \mathrm{O}$. Above $\mathrm{pH} 9.5$ there was an anionic species which was subject to rapid auto-oxidation.

\section{$\underline{\text { Europium }}$}

At $\mathrm{pH} 13.3$, the complex was found to be $\operatorname{EuGl}(\mathrm{OH})_{4}$. The derived value was $\log \beta=24.3$ \pm 0.3 , assuming that the significant species present was $\operatorname{Eu}(\mathrm{OH})_{4}{ }^{-}(\log \beta=18.52$ [12] $)$. The Schubert plot also showed an Eu:Gl ratio of 1:1.

\section{$\underline{\text { Holmium }}$}

At $\mathrm{pH} 13.3$, the stoichiometry was determined to be $\mathrm{Ho}_{2} \mathrm{Gl}(\mathrm{OH})_{6}$. The derived value was $\log \beta=49.8 \pm 0.4$ assuming that the significant species present was $\mathrm{Ho}(\mathrm{OH})_{4}{ }^{-}(\log \beta=17.2[12])$.

\section{$\underline{\operatorname{Iron}(I I)}$}

At $\mathrm{pH} 13.3$, the complex was determined to be $\mathrm{FeGl}(\mathrm{OH})_{4}$, which gave a $\log \beta$ value of 17.8 \pm 0.9 . The $\mathrm{A}$ term was calculated on the assumption that the significant hydrolysis species present were $\mathrm{Fe}(\mathrm{OH})_{3}{ }^{-}(\log \beta=13)$ and $\mathrm{Fe}(\mathrm{OH})_{4}{ }^{2-}(\log \beta=10)[7]$.

\section{$\underline{\operatorname{Iron}(\text { III) }}$}

At $\mathrm{pH} 13.3$, the complex was determined to be $\mathrm{FeGl}(\mathrm{OH})_{3}$, with $\log \beta=37.9 \pm 1.2$. The $\mathrm{A}$ term was calculated assuming the only significant species present was $\mathrm{Fe}(\mathrm{OH})_{4}{ }^{-}(\log \beta=34.4$ [7]). The Schubert plot showed an Fe(III):GL ratio of 1:1. In other studies of this system, $\mathrm{FeGl}(\mathrm{OH})^{2-}$ and $\mathrm{FeGl}(\mathrm{OH})_{4}{ }^{2-}(\log \beta=37.2)$ were found at high $\mathrm{pH}[17]$, as well as $\mathrm{Fe}_{2} \mathrm{Gl}_{2}(\mathrm{OH})^{-}$, $\mathrm{Fe}_{2} \mathrm{Gl}_{2}(\mathrm{OH})_{3}{ }^{-}, \mathrm{FeGl}^{-}$and $\mathrm{FeGl}(\mathrm{OH})^{2-}$ [18]. Zay et al. [19] observed FeGl $(\log \beta=9.63)$ and $\mathrm{Fe}_{2} \mathrm{Gl}(\log \beta=9.63)$. Kaminski [20] measured the constants for $\mathrm{FeGl}(\mathrm{OH})^{2-}(\log \beta=5.7)$, and also observed $\mathrm{FeGl}(\mathrm{OH})_{2}{ }^{2-}$ and $\mathrm{FeGl}(\mathrm{OH})_{3}{ }^{3-}$. Nagy et al. [21] found the species $\mathrm{Fe}_{2} \mathrm{Gl}_{2}(\mathrm{OH})_{4}\left(\mathrm{H}_{2} \mathrm{O}\right)_{2} \mathrm{Na}_{2}$ at $\mathrm{pH} 10$ to 12 .

\section{$\underline{\operatorname{Uranium}(V I)}$}

At near-neutral $\mathrm{pH}$ the complex was determined to be $\mathrm{UO}_{2} \mathrm{Gl}$. The measured stability constant was $\log \beta=6.3 \pm 0.4$. The A term was calculated assuming the significant species present were; $\mathrm{UO}_{2} \mathrm{OH}^{+}\left(\log \beta=7.7\right.$ [7] and $\mathrm{UO}_{2}(\mathrm{OH})_{2}(17.25$ [12]). Sawyer [22] measured the constant for the complex $\mathrm{UO}_{2} \mathrm{Gl}(\mathrm{OH})_{2}(\log \beta=6.25)$. 


\section{The solubility product method for measuring stability constants}

The solubility of $\mathrm{Na}_{2} \mathrm{U}_{2} \mathrm{O}_{7}(\mathrm{am})$ at $\mathrm{pH} 13.3$ in Gl-free samples was measured to obtain a value for the solubility product. A value of $\log \mathrm{K}_{\mathrm{sp}}=-57.5$ was obtained. The A term was calculated assuming that the significant species were $\mathrm{UO}_{2}(\mathrm{OH})_{4}{ }^{2-}$ and $\mathrm{UO}_{2}(\mathrm{OH})_{3}{ }^{-}(\log \beta=22.2$ for both [7]). Determination of a stability constant, using the method of Warwick et al. [6] gave $\log \beta=19.9 \pm 2$ for $\mathrm{U}(\mathrm{VI})-\mathrm{Gl}$.

\section{CONCLUSIONS}

Each complex formed at near-neutral $\mathrm{pH}$ was of the form $\mathrm{M}_{1} \mathrm{Gl}_{1}$, with $\log \beta$ values in a range suggestive of salt formation, except the oxycation $\mathrm{UO}_{2}{ }^{2+}$ for which $\log \beta=6.3$. In all cases, except $\mathrm{U}(\mathrm{VI}), \mathrm{OH}^{-}$ions have been involved in the formation of complexes at high $\mathrm{pH}$. It is not clear whether the $\mathrm{OH}$ group was coordinated to the cation in addition to the gluconate, or if chelate complexes were formed with the consequent elimination of hydrogen ions from the ligand, e.g. the equation for the formation of the $\mathrm{Cd}$ complex at high $\mathrm{pH}$ could be (equations 4 and 5):

$$
\begin{aligned}
& \mathrm{Cd}^{2+}+\mathrm{Gl}^{-}+2 \mathrm{OH}^{-} \rightarrow \mathrm{CdGl}^{-}+2 \mathrm{H}_{2} \mathrm{O} \text { or } \\
& \mathrm{Cd}^{2+}+\mathrm{Gl}^{-}+2 \mathrm{OH}^{-} \rightarrow \mathrm{CdGl}(\mathrm{OH})_{2}{ }^{3-}+2 \mathrm{H}^{+}
\end{aligned}
$$

More work is required to determine which of these possibilities is applicable to each complex [6]. However, for the purposes of consistency in this paper the stoichiometry of the complexes has been written as though the $\mathrm{OH}$ groups are co-ordinated to the metal. At $\mathrm{pH} 13.3$ the divalent cation constants were in the region $\log \beta=13$ to 20 , with $2 \mathrm{OH}^{-}$ions being involved in their formation, apart, again, from U(VI). For the trivalent cations, there appears to be less consistency in the results. The $\mathrm{M}_{2} \mathrm{~L}$ complexes (Ce and Ho) have $\log \beta$ values of 43.9 and 49.8 , whereas the ML type range from 24.3 (Eu) to 37.9 (Fe(III)). This may be due to the different number of $\mathrm{OH}^{-}$ions involved in their formation. These constants have enabled speciation calculations to be performed using the speciation programme JCHESS [12], showing the effect of gluconate on the solubility of the metals. Of particular interest is the effect in the near field and the alkaline-disturbed-zone. To show this a solubility enhancement factor was determined; defined as:

$$
\text { Enhancement Factor }=\frac{\text { metal solubility in presence of gluconic acid }}{\text { metal solubility in absence of gluconic acid }}
$$

Figure 3 shows the variation of enhancement factor against $\mathrm{pH}$ for all di- and trivalent cations for which high $\mathrm{pH} \log \beta$ values are known. For most radionuclides used in this study solubility increases between $\mathrm{pH} 9$ and 13.5, indicating that gluconate may have a major impact on the behaviour of radionuclides in the near field of a cementitious repository. The largest increases, between $10^{3}$ and $10^{6}$, are for $\mathrm{Cd}, \mathrm{Co}, \mathrm{Eu}, \mathrm{Ho}$ and $\mathrm{Ni}$. The increase for most metals falls at higher $\mathrm{pH}$ as hydrolysis products become more significant. The smallest effect is on U(VI). The data determined in this study will help to develop the understanding of the effects of gluconic acid and similar complexants on the migration of radionuclides. 


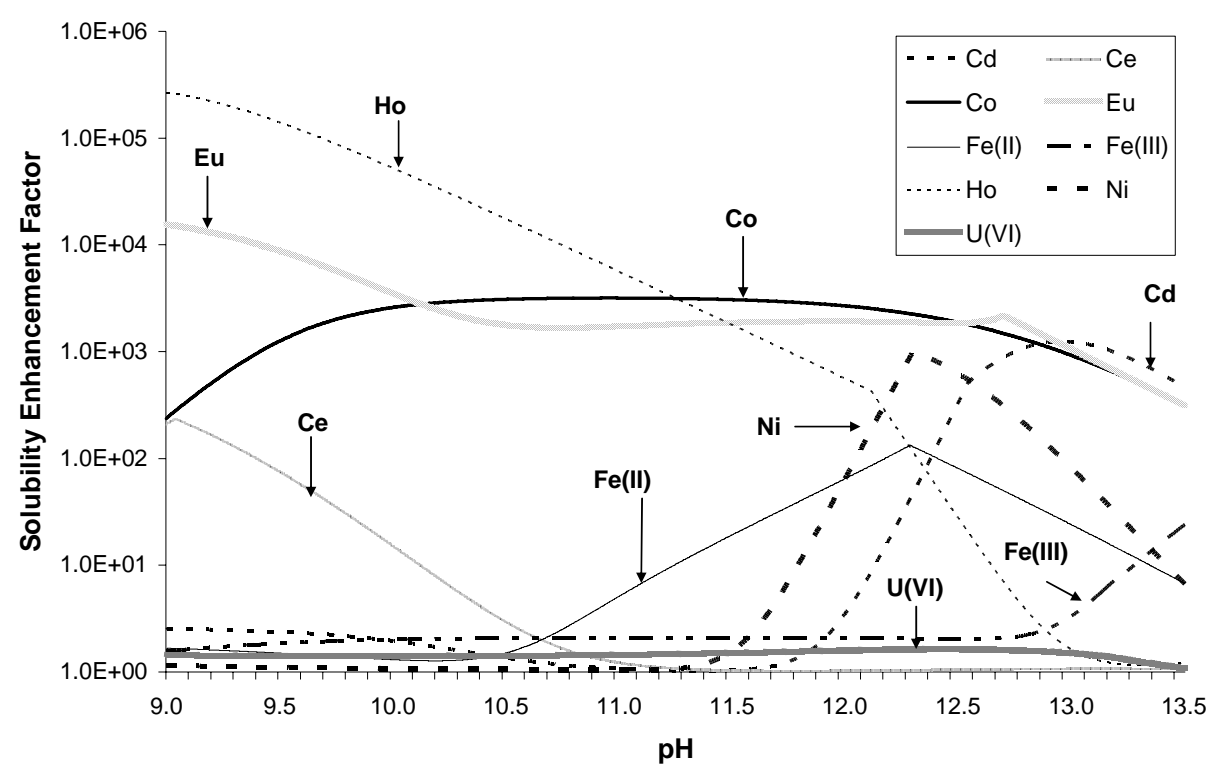

Figure 3. Variation of solubility enhancement factor with $\mathrm{pH}$

\section{REFERENCES}

[1] United Kingdom Nirex Ltd, Nirex Report N/074, (2003)

[2] X. Bourbon and P. Toulhoat, Radiochim. Acta, 74, 319 (1996)

[3] J. Tits, E. Wieland, M. H. Bradbury and J-P. Dobler, J. Conf. Abst. 5(2), 1009 (2000)

[4] P. Warwick, N. Evans, A. Hall, and S. Vines, Radiochim. Acta 91, 233 (2003)

[5] A. Maes, J. De Brabandere and A. Cremers, Radiochim. Acta 44/45, 51 (1988)

[6] P. Warwick, N. Evans, A. Hall, and S. Vines, Radiochim. Acta 92, 897 (2004)

[7] A. Martell and R. Smith, Critical Stability Constants, Vol 3, Plenum, New York, (1989)

[8] K. Blomqvist and E. Still, Anal. Chem., 57, 749 (1985)

[9] G. A. Melson and W. F. Pickering, Aust. J. Chem., 21, 2889, (1968)

[10] R. L. Pecsok, J. Am. Chem. Soc., 77, 1489 (1955)

[11] G. Marcu and G. Murgu, Rev. Roum. Chim., 12, 957 (1967)

[12] J. Van der Lee, École des Mines de Paris, Fontainebleau, France (2002).

[13] W. F. Pickering and J. Miller, J. Proc. Roy. Soc. N.S. Wales, 92, 73 (1958)

[14] F. B. Martinez and G. B. Miguez, Z. Anal. Chem., 253, 353 (1971)

[15] J. F. Ashton and W. F. Pickering, Aust. J. Chem., 23, 1367 (1970)

[16] L. I. Katzin and E. Gulyas, J. Am. Chem. Soc., 92:5, 1211 (1970)

[17] R. L. Pecsok and J. Sandera, J. Am. Chem. Soc, 77, 1489 (1955)

[18] J .Gonzalez-Velasco, J. Ortega and J. Sancho, J. Inorg. Nucl. Chem., 38, 889 (1976)

[19] I. Zay, F. Gaizer and K. Burger, Inorg. Chim. Acta, 80, L9 (1983)

[20] W. Kaminski, Roczniki Chemii Ann. Soc. Chim. Polonorum, 46, 339, (1972)

[21] L. Nagy, K. Burger, J. Kürti, M. A. Mostafa, and I. Kiricsi, Inorg. Chim. Acta, 124 (1986)

[22] D. T. Sawyer and R. J. Kula, Inorg. Chem., 1(2), 303 (1962) 